\title{
SPRAWOZDANIE
}

\section{SPRAWOZDANIE Z KONFERENCJI „THE NORDIC GEOGRAPHERS MEETING”, SZTOKHOLM 18-21 CZERWCA 2017}

W dniach 18-21 czerwca 2017 r. miała miejsce w Sztokholmie konferencja naukowa „The Nordic Geographers Meeting”, która była już siódmym z kolei spotkaniem geografów specjalizujących w problematyce społecznej i ekonomicznej. W większości, zgodnie z założeniem, w konferencji uczestniczyli geografowie z państw nordyckich. Inicjatywa ma formułę otwartą, stąd też udział wzięli również przedstawiciele $\mathrm{z}$ innych państw europejskich, a także spoza naszego kontynentu (łącznie ok. 800 badaczy). Głównym organizatorem był Instytut Geografii Człowieka Uniwersytetu Sztokholmskiego, a przewodniczącą komitetu organizacyjnego - prof. Gunnel Forsberg.

Motywem przewodnim konferencji był problem geografii nierówności (geographies of inequalities), który ściśle wiąże się z szerszym zagadnieniem jakim są nierówności społeczne i ekonomiczne w różnych skalach przestrzennych. Organizatorzy w prezentacji problematyki konferencji słusznie zauważyli, że zrozumienie nierówności przestrzennych leży w centrum badań geograficznych a pytania badawcze stawiane w tym zakresie są bardzo ważne w różnych paradygmatach naukowych współczesnej geografii człowieka. Dlatego dużo uwagi podczas konferencji poświęcono związkowi segregacji społecznej, ekonomicznej $\mathrm{i}$ etnicznej $\mathrm{z}$ procesem planowania przestrzennego, zwłaszcza obszarów zurbanizowanych. Kwestia ta w opinii organizatorów powinna pozwolić na ocenę konsekwencji migracji różnych typów, zwłaszcza wielkich ruchów ludności spowodowanych kwestią nierówności w skali świata i kontynentów. Problemem wskazanym przez gospodarzy jako istotny do rozważań było zagadnienie nierówności manifestujących się w krajobrazie, co prowadzi do odkrycia widocznych i niewidocznych relacji władzy we współczesnym świecie. Wśród innych wymiarów nierówności zwrócono uwagę na problematykę płci kulturowej, społeczności lokalnych, nowych czynników rozwoju regionalnego (odporności na kryzysy) oraz uwarunkowania środowiskowe (np. zmiany klimatyczne). Zakres merytoryczny konferencji został określony m.in. przez zaproszenie do najważniejszych prezentacji badaczy zajmujących się problematyką nierówności, tj.

1) prof. Irene Molina, która przedstawiła kluczowe problemy nierówności na tle rasowym, etnicznym, klasowym i płci kulturowej oraz obecnie podejmowane w tym zakresie badania w Szwecji, zwłaszcza dotyczace kształtowania się zasobów mieszkaniowych;

2) prof. Don Mitchell, który odniósł się do wytwarzania się krajobrazu kulturowego w efekcie przemian stosunków produkcji i rynku pracy, ze szczególnym uwzględnieniem wykluczania marginalizowanych grup. W swoim wystąpieniu skupił się na ekonomii politycznej krajobrazu, teorii społecznej oraz geografii władzy i marginalizacji w przestrzeni;

3) prof. Johan Rockström, który skoncentrował się na problematyce zrównoważonego rozwoju i jego roli w kształtowaniu bezpiecznej przestrzeni dla ludzkości oraz zastosowania prac naukowych w praktyce politycznej i biznesowej.

Sesje zorganizowano w następujących blokach problemowych: dzieci i młodzież, planowanie rozwoju, geografia ekonomiczna, edukacja, badania nad środowiskiem i zrównoważonym rozwojem, płeć kulturowa, geografia nierówności: teoria i metodologia, mieszkalnictwo - segregacja i dobrostan, migracje i mobilność, geografia polityczna, studia wiejskie, turystyka, urbanistyka. Uczestnicy mogli wziąć udział również w ses- 
jach terenowych, głównie w przestrzeni stolicy Szwecji, gdzie motywami przewodnimi było funkcjonowanie instytucji i przestrzeni publicznych. Atrakcją było również zorganizowanie wieczoru towarzyskiego w Winterviken, w dawnej fabryce A. Nobla, obecnie zrewitalizowanej na potrzeby organizacji spotkań, konferencji i innych wydarzeń.

Konferencja dowiodła jak rozległe jest zagadnienie badań geografii nierówności oraz rozmaitość ujęć teoretycznych i metodologicznych. Istotną kwestią było również wskazanie roli geografów w opisie i, co ważniejsze, w rozwiązywaniu problemów społecznych w różnych skalach przestrzennych. Aplikacyjność badań przy dużej świadomości teoretyczno-metodologicznej jest jednym z największych walorów skandynawskiej geografii, która utrzymuje niezmiennie wysoką pozycję w Europie i na świecie.

Marcin Wójcik Katedra Geografii Regionalnej i Społecznej Uniwersytet Łódzki 